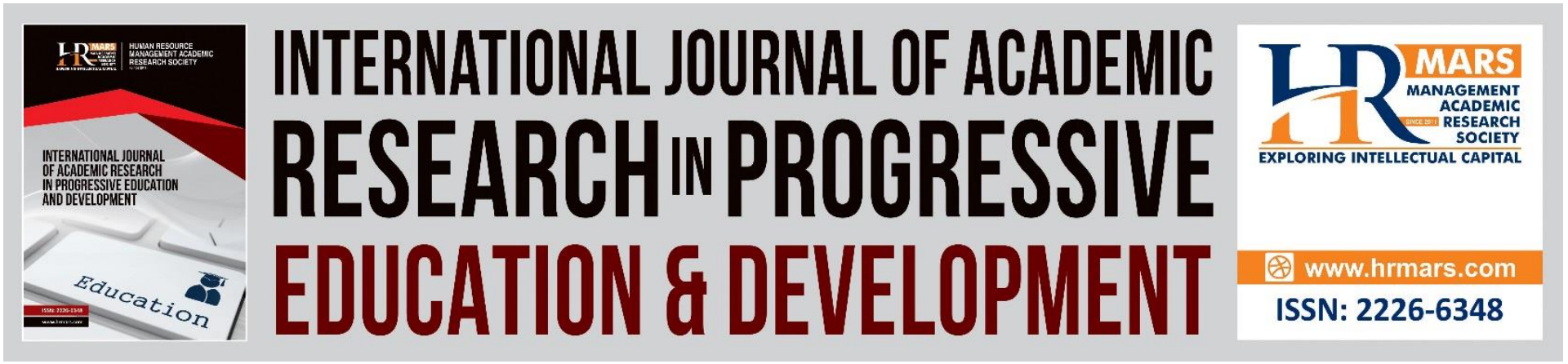

\title{
ESL learners' transitional Readiness to Mobile Blended Learning Mediamorphosis
}

Tengku Intan Suzila Tengku Sharif, Mohd Yusri Mohamad Noor, Omar, S.R. and Teo, K. S

To Link this Article: http://dx.doi.org/10.6007/IJARPED/v10-i3/10419

DOI:10.6007/IJARPED/v10-i3/10419

Received: 10 June 2021, Revised: 13 July 2021, Accepted: 17 July 2021

Published Online: 20 August 2021

In-Text Citation: (Sharif et al., 2021)

To Cite this Article: Sharif, T. I. S. T., Noor, M. Y. M., Omar, S. R., \& Teo, K. S. (2021). ESL learners' transitional Readiness to Mobile Blended Learning Mediamorphosis. International Journal of Academic Research in Progressive Education and Development, 10(3), 202-212.

Copyright: (C) 2021 The Author(s)

Published by Human Resource Management Academic Research Society (www.hrmars.com)

This article is published under the Creative Commons Attribution (CC BY 4.0) license. Anyone may reproduce, distribute, translate and create derivative works of this article (for both commercial and non-commercial purposes), subject to full attribution to the original publication and authors. The full terms of this license may be seen at: http://creativecommons.org/licences/by/4.0/legalcode

Vol. 10(3) 2021, Pg. 202 - 212

http://hrmars.com/index.php/pages/detail/IJARPED

JOURNAL HOMEPAGE

Full Terms \& Conditions of access and use can be found at http://hrmars.com/index.php/pages/detail/publication-ethics 


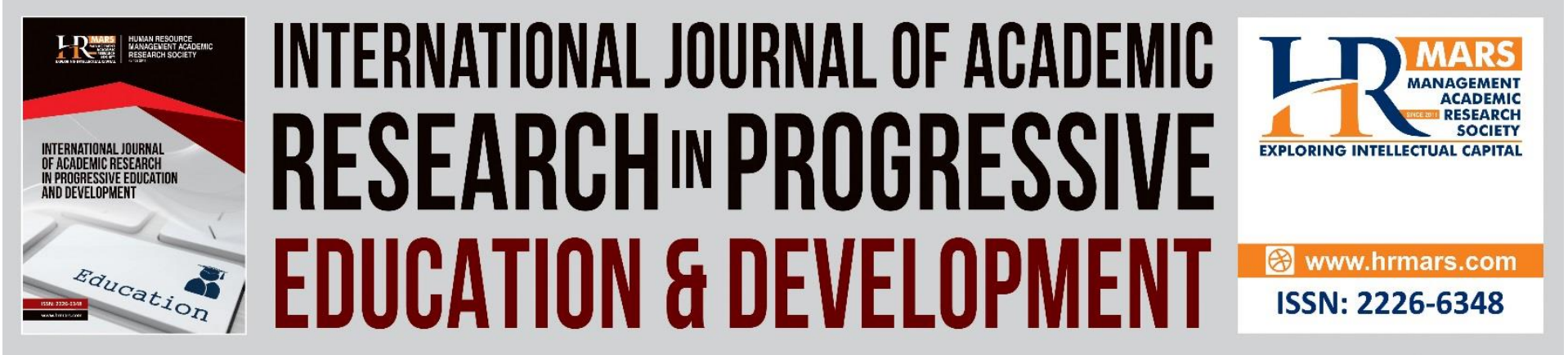

\title{
ESL learners' transitional readiness to Mobile Blended Learning Mediamorphosis
}

\author{
Tengku Intan Suzila Tengku Sharif ${ }^{1}$, Mohd Yusri Mohamad \\ Noor ${ }^{2}$ and Omar, S.R. ${ }^{3}$ \\ and Teo, K. S ${ }^{4}$ \\ ${ }^{1 \& 2}$ Academy of Language Studies, Universiti Teknologi MARA Pahang, Jengka, Pahang, \\ Malaysia, ${ }^{3}$ Centre for Environment and Sustainability, Universiti Teknikal Malaysia Melaka, \\ Melaka, Malaysia, ${ }^{4}$ Institute of Ethnic Studies, Universiti Kebangsaan Malaysia, Bangi, \\ Selangor, Malaysia \\ Email: mohdyusri@uitm.edu.my
}

\begin{abstract}
Mediamorphosis is no longer just a concept in blended learning (BL) classes. During the Covid19 pandemic, students have no option but to endure such media transitions in in open distance learning (ODL) which adopts similar technological use in BL. The present study explores how mediamorphosis in mobile BL affects tertiary level foundation students' learning English language as second language (ESL). The problem that led to the study is the students' level of readiness for changes in English language teaching (ELT) mediums. The objective of this study is to unfold the students' ability to grasp the subject content within the mediamorphic mobile setting. A qualitative approach was adopted to report average learners' feedbacks and to understand the nature of the learners' acceptance and comprehension of the subject content when taught through Mobile Blended Learning Application (MoBL) as opposed to the traditional method. The method assumed were a partial observation method in mobile setting and online interview. Analysis was made using thematic and discourse analysis convention and observations were recorded and themed focusing on method, presentation and content. Recorded observations were made through lectures of one semester and interviews were carried out with two small focus groups - male and female. The findings suggest that lecturers' role in accommodating students' needs and readiness in MoBL mediamorphosis is vital. The significance of the study is the findings will enable ELT to be more adaptive to students' mixed level of mediamorphosis acceptance. The novelty of the study is it refuses a generalization based on data collected using perception-type questionnaire and offering a more in-depth overview of the matter and focuses on ESL average learners only.
\end{abstract}

Keywords: Average Learners, ELT, Blended Learning, Mobile Learning, Mediamorphosis. 


\section{Introduction}

eLearning has been implemented in Malaysia for 22 years since 1996 (Puteh, 2007). Therefore, Malaysian students are perceived to have grasped a strong foundation in eLearning. Analysis on students' satisfaction and criteria for improvement of eLearning (Wu et al., 2010) and educational accomplishment (Paechter et al., 2010) have been countlessly explored. eLearning claimed to amplify students' learning attentiveness, drive and improve attention (Kuo et al., 2013). These discoveries are not specific to the Malaysian scenario (see Puteh, 2007).

In blended learning (BL), where teaching using technology was embedded, course work products have also seen some elevation (Khodeir, 2018). But technology-equipped classroom implementation is remote from expectation (Abdul Majeed \& Muslim, 2016). Their findings proposed two deductions: firstly, there is inadequate knowledge in using technology in teaching, and secondly, there is no structured technological teaching method suggested as it is not included in the curriculum.

Abdeen (2016) stressed that adopting technological customs in a classroom is inevitable and that training courses for teachers to assemble technologically literate educationalists is also essential. The process of integrating technology is the teachers' vital, conscious and planned responsibility to fulfil in order to ensure significant contributions to the growth of e-ELT (Gunuç \& Babacan, 2017).

In short, although no ELT classroom can be isolated from technological advancement in education, Malaysian educationalists have yet to formulate a curriculum that motivates teachers and students' abilities in absorbing technological based knowledge. Malaysian teachers and students should have by now been well-equipped with technological knowledge and skills.

\section{Mediamorphosis and ELT}

Mediamorphosis, a designated term for 'media-changes', refers to the "transformation of communication media, usually brought about by the complex interplay of perceived needs, competitive and political pressures, and social and technological innovations" (Fidler, 1997). Jiménez (2014) observed numerous technologies have penetrated the language classroom and digital tools are a good option for online distance learning during the present Covid 19 pandemic as teachers' usage of digital tools serves as a motivation to students. "Some people may argue that grammar courses have a lot of content and very few hours per class thus teachers do not use digital tools" (Jiménez, 2014, p. 14) but teachers must still adapt.

\section{English Language Teaching (ELT)}

ELT in Malaysia has evolved tremendously from typical 'chalk and talk,' grammar drills and nursery rhymes to learn pronunciation skills. As claimed by Nomass (2013), the traditional teaching methods in English language learning (ELL) have their flaws. The methods are generally deemed as slower, unexciting and thus have a demotivating effect on the students because it is still teacher-centred in comparison to the modern technical ways that allow the education process to be more student-centred. Ultimately, the classical methods are based on theory rather than practice.

Despite the limitations of traditional teaching approaches as suggested above, Nomass (2013) earlier wrote "the technical capabilities of their college are almost poor, and there was a weak tendency of encouraging students to use technology in the classroom lessons" (p. 15). This 
one major constraint of technology-based teaching and learning may easily set off a larger frustration in ESL classroom.

Like most perceived study outputs, results of the case study showed that "most of the students prefer the use of technology, especially computers, in developing their second language skills" (Nomass, 2013, p. 115). However, preference does not necessarily translate to comprehension of ESL and high proficiency or achievement in ESL. It is undeniable that technology is rapidly progressing, thus, these assumptions were concluded (Nomass, 2013):

a) the use of technology in the classroom is inevitable,

b) the use of computer is becoming an integral component as it is being used to transfer skills to the learners,

c) theories in second language learning can now be practiced with the use of modern technology,

d) second language learning and teaching will become more effective with the use of modern technical ways,

e) students should be encouraged to use technology to develop their language skills,

f) education institutions should update their equipment and laboratories to support the teaching process.

There is no denial of rampant technological influx in ELT, yet it is fundamental to warrant that the varieties in students' learning styles are considered to ensure effective implementation of the said technologies.

\section{Mobile English Language Learning}

Dzakiria et al. (2005) studied the ODL concepts and unfolded some problems and challenges. These are similar to most current studies on ODL (Self, 2021; Wen \& Tan, 2020; Huang et al., 2020; Arulogun et al., 2020; Kamarulzaman \& Siew, 2020). This is also similar to Blended learning (BL), which was first utilized in an enterprise training in the 1990s, however, its progression to education was perhaps without proper deliberation of students' adaptability and readiness (Li, 2015). Although Palacios' (2016) findings implied that a BL approach that comprises of techniques, strategies, and activities on Moodle, intensifies lexis and reading and also motivates greater interest in students, they agreed that the study necessitates the employment of a wider population. The study not only adopted perceived survey method, it also only targeted above average school achievers.

Age is another factor to be considered when applying mediamorphosis. Apart from Kahoot, Edmodo, and Padlet, among other teaching tools, MoBL (Mobile Blended Learning Application) was also developed for use in a mobile blended learning setting (Suzila et al., 2018). During the Covid-19 pandemic movement control order (MCO), these platforms enable students to be less restrained to a desk, mobile within the comfort of their home and thus, may reduce stress. However, senior secondary EFL students are warned "to learn the materials carefully, read the passages seriously, and answer all the exercises carefully, not by doing 'trial and error'" (Wibisono, 2019, p.103) when using Kahoot. Kimura's (2018) use of Padlet for upper-intermediate Japanese EFL students simply used Google Docs or Slides to minimise negative effects of mediamorphosis. Similarly, Suzila et al (2018) employed WhatsApp application as a familiar platform to minimise distractions from mediamorphic elements in blended learning. Yusuf et al. (2018) claimed that senior high school students' writing of narrative texts showed improvement with the use of Edmodo, yet the findings were obtained from a simple open-ended questionnaire which may report perceived output rather 
DEVELOPMENT

Vol. 10, No. 3, 2021, E-ISSN: 2226-6348 @ 2021 HRMARS

than actual academic performance. In addition, the research limitation is the validity of the collected comments by students in Edmodo may not abide to pre/post-test conventions.

\section{Method}

The present study utilises a qualitative approach of recording partial observation and interviews. The study involves average proficiency Malaysian Secondary School certificate (SPM) achievers undertaking foundation course for diploma at a local university. The 'foundation students' here refers to students of average academic achievement at secondary level possibly with lower socioeconomic background. The aims of the study are to explore: (1) students' ability to grasp the subject content within the mediamorphic MoBL setting; and (2) perceived improved academic performance in ELL.

\section{Conceptual Framework}

The conceptual framework of the present study is adapted from Ikram (2015) who suggested a mixed method approach to study the impact of video technology on pre-schoolers. Three criteria are focused on to reveal the nature of average students' readiness and perceived improved academic performance of ELL. Figure 1 shows the conceptual framework of the present study.

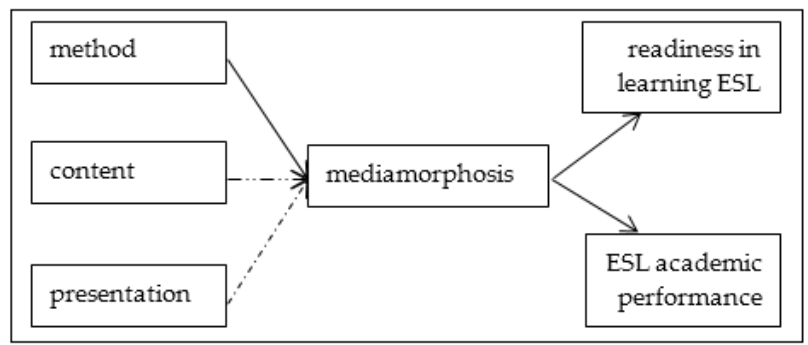

Fig. 1: Flow chart of conceptual framework

Firstly, these average students are exposed to several media learning methods upon registering to the university foundation course. This includes engagement to contents in Ufuture as blended learning platform, e-based assessments and eLearning teaching and learning approach in classroom. Ufuture is a proprietary online learning management system managed by the local university for its students which allows lecturers to upload teaching materials in pdf, pptx, docx formats even video clips. Yet, server congestion and difficulty to navigate on smartphones are among the potential setbacks. The activities include consultation with lecturers through WhatsApp, Padlet and Ufuture chat; recorded lectures using Prezi, PowerPoint, or video; online newspapers, blended learning hours and traditional 'chalk and talk' teaching method.

The presentation of the content above was used alternately. Students are provided with lesson plans. The recorded presentation of the "chalk and talk" teaching technique is carried out as the lecturer teaches the class, she writes notes, and doodles to explain components of each lesson. Students are allowed to snap pictures of the notes written on the whiteboard using their smartphones if they did not have time to write it down. 
DEVELOPMENT

Vol. 10, No. 3, 2021, E-ISSN: 2226-6348 @ 2021 HRMARS

\section{Research Design}

The present study adopts the qualitative approach as a means to better understand the readiness and perceived improved performance in ELL. A study of a group of ELL foundation students using MoBL mediamorphosis over a period of one semester is therefore conducted.

\section{Sampling}

A class of foundation students consisting of 32 students, 17 males and 15 females, were conveniently and partially observed and later separately interviewed.

\section{Procedure}

Recorded observations were focused towards students' reactions, attention and willingness to participate in online classes. The complete observant method is adopted here. Recorded observation is sometimes carried out discretely by a student or openly by the lecturer. Dwyer (2006) adopted discrete recorded observation field data collection method as a means to eliminate researchers' bias. This technique also minimized observer's paradox (Labov, 1972). Although some argued that it may be unethical, Bowern (2008) concluded that to eradicate observer's paradox is essential and permission is requested later. Recorded interviews were carried out in two small focus groups by segregation according to gender and guided by themes which fulfil the research objectives. These interviews were transcribed and thematic analysis was carried out. Production of e-posters as required by the syllabus serves as evidence of improved performance in English language learning. E-posters are produced by the students at the end of the semester. Creativity and language used are part of the assessed criteria of an e-poster.

\section{Analysis}

Interviews were transcribed and themed inductively. Among the themes include memory of learned topics, and feelings - positive and negative during doing the activities. Figure 2 below summarizes the plus and minus themes.

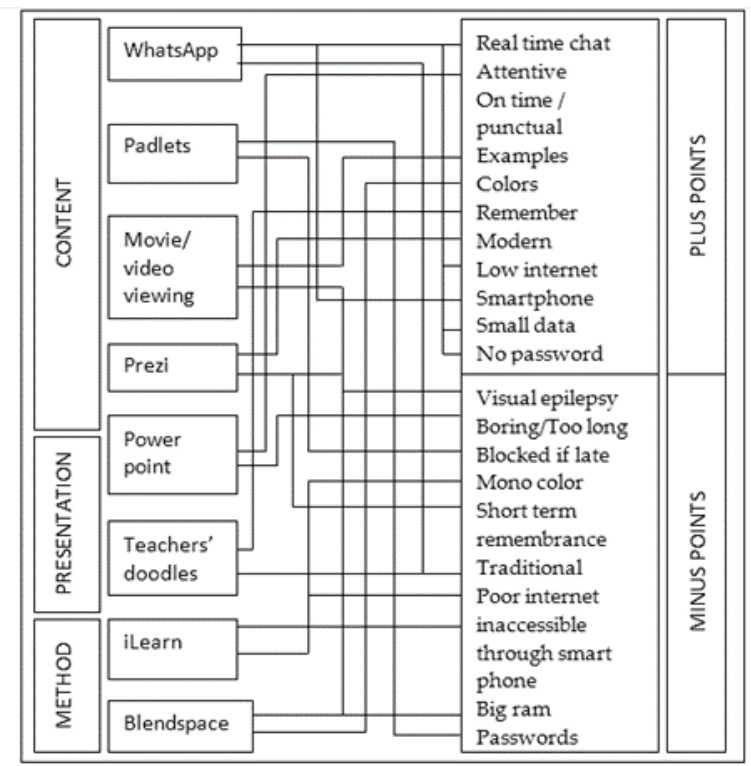

Fig. 2: Pro's and Con's to Technology in ELT 


\section{Findings}

Students' reactions towards the method, content and presentation were positive. Attentiveness in class was good during online learning unlike during "chalk and talk" sessions. Students' attendance was good but this has many other contributing factors such as constant reminders and probing.

However, perceived performance was poor. Willingness to participate in class was still low. Both male and female students anticipated the eLearning teaching approach and the need to use Ufuture yet this is mainly a one-way communication for asynchronous learning platform. It saves internet data but loses the humanistic essences.

The male students were aware and ready for eLearning in university environment unlike a few female students. Many express their concern for strong Wi-Fi connection. eLearning satisfaction can be influenced by technology quality and internet quality (Piccoli et al., 2008). Thus, without university's Wi-Fi connection, students are financially burdened.

E-based assessments overwhelmed them. The quality of e-poster which was part of their eassessment was also poor although students claimed to enjoy and want to continue with eassessment. Language structure and grammar used are among the weaknesses in e-posters although the portrayal of creativity was almost excellent.

ID6: buat e-poster tu best. Boleh guna komputer, belajar komputer. (making e-poster is good. I get to use computer, and learn computer skill)

These average students were excited, satisfied and were able to engage with the content and motivated by mediamorphosis yet all these did not boost their ability to improve in ELL. Their focus was directed towards the wonders of experiencing mediamorphosis but failed to comprehend the English learning content and to remember any presentations. Thus, the students' observed positive behaviours towards mediamorphosis have been misinterpreted. Attentiveness through mediamorphosis did not corelate positively with learning comprehension.

ID18: saya refer video yang puan beri, lepas tu tengok juga pdf yang ada tu...(tapi) masa test tak ingat lah semua (I referred to the videos and pdf given but during the test I don't remember all)

ID23: paham rasanye cuma tak reti nak cite (I understand, I think, but can't explain)

ID26: tak perasan puan, ingat terbang-terbang je (didn't notice, remember flying notes (in Prezi) only)

The 'chalk and talk' sessions filled the learning gaps caused by mediamorphosis. Both male and female students still needed written notes on the white board. The students also claimed to appreciate the lecturer constantly checking their comprehension as opposed to after 2 hours' movie or 5 minutes' video viewing sessions. These suggest that students are ready for only MoBL one-way mediamorphosis environment, yet it does not guarantee improved performance in ELL.

16: best tapi tak ingat lah, puan lukis ingat lah (don't remember, but remember the one you drew) 
29: saya ingat peta Serawak yang puan lukis, in Kuching, at Taman Miau, in Taman Miau, at Lorong Cat (I remember the Sarawak map you drew...)

\section{Discussion}

Figure 2 above shows that each observed teaching methods, presentations and contentbased approaches have both advantages and disadvantages to average ESL learners. Using WhatsApp for mobile learning, for example, may pose health risk e.g., visual epilepsy for some students when vivid flashing media files are used rampantly. The mobile mediamorphosis can be tiring particularly when it is in a single theme conversation thread on a small screen for a lengthy period. Students can also get mental block, or lost track of the communication thread when they are late in joining the online class. Media used can also be monotonous in colour and confusing in tone. Students' also do not remember much of the discussed topics (short term memory of the topic) and may resort to employ traditional conversation conventions. These may incur negative perception and comprehension of lessons led by poor discourses. Some average students feel they are more attentive, on time / punctual to join the online conversations. They can share notes asynchronously online and have more time to retrieve examples thus can remember some points better. They, like any other students, enjoy the modern approach to learning. WhatsApp also demands only low internet bandwidth, and allow mobility as it is used on smartphones. This requires minimal data usage and does not require class password like Edmodo (Tengku Intan Suzila et al., 2018).

The present findings are paralleled to Solano et al. (2017) where their findings too confirmed that currently, neither technology is sufficiently utilized nor is it totally benefited by all types of students. The findings of the present paper also corresponded to the previous research (Paechter et al., 2010; Gunuç \& Babacan, 2017) including Alfaleh (2015) where ESL reading school accomplishments or reading enthusiasm are not influenced by the convenience or lacking of technology.

Parsa (2015) supported the present findings that only excellent students may gain significantly from internet learning particularly through mediamorphosis. Special attentiveness is thus needed if an ELL class is of a mixed level of English proficiency.

\section{Conclusion}

Ruiz et al. (2006) agreed that learners' satisfaction rate increase with eLearning compared to traditional learning, yet high correlation with learning achievement is yet to be unfolded. Surveys seen in Wu et al. (2010), Paechter et al. (2010) and Kuo et al. (2013) to mention a few, offer negligible generalization. Thus, students' genuine and unconscious reactions in the present study observed and recorded may propose worthier insights.

Technology used in MoBL classroom is important and unavoidable as it does have many benefits yet it demands appropriate objectives and proper considerations to ensure success. It is essential that a lecturer understands and adapts to the students' aptitudes as opposed to furnishing the pressure of being abreast with academic learning changes, requirements and demands. Planning before adopting technology in ELT is significant (Gunuç \& Babacan, 2017). It is a prerequisite that appropriate and suitable ELT strategies are employed in classrooms. Smooth landing from conventional learning environment to eLearning is vital and lecturers hold great responsibilities to ensure such positive experience for the students.

Concurrent with the pandemic, theoretically, instructional ODL or MoBL material designs must consider the movement from one media to another or mediamorphosis to be reduced 
to perhaps 2 to 3 media within a lesson. To allow continuous learning motivation, material developers may adopt a diverse media in different chapters. This must be tested for further certification of the most bearable number of media changes within one lesson to another. Any material developers must strain themselves from being overzealous in attempting all kinds of technologically savvy medium of instructions available. A lesson cannot consist of notes in flipbooks, videos in YouTube channels, and perhaps an app to conduct activities followed by a quiz in Quizzies. These changes are in theory troublesome and aggravate anxiety.

Contextually, in ELL, education administration may reconsider their demands for content developers to produce as many technologically advanced materials to be adopted as teaching materials and limits the number of learning management systems (LMS) used. Content developers may need to revise their materials at par to the students' needs. They can opt to use available native speakers' resources which can benefit the ESL students.

Most studies (Self, 2021; Wen \& Tan, 2020; Huang et al., 2020; Arulogun et al., 2020; Kamarulzaman \& Siew, 2020) on learning during the pandemic have focused on students' emotions and readiness to cushion the changes from face to face (F2F) learning to open distance learning (ODL).

Based on Abdul Muin (2021), ODL students can be 'isolated self-regulated' and 'isolated disengaged' in ODL. Both 'isolated self-regulated' and 'isolated disengaged' ODL students may suffer from mediamorphosis in MoBL/ODL materials which can be one of the causes to disengagement, overwhelming and lost. This study is significant to further add to the existing knowledge that any MoBL and ODL materials must reconsider mediamorphosis effect to students' learning and health.

Mediamorphosis in MoBL and ODL materials may also halt learning as it takes huge data use and material loading time especially if one is frequently moving from a video to an apps or one video to another type of notes e.g. in pdf or pptx in any LMS. In this challenging times, financially burdening measures need to be re-considered.

Despite many studies of the technological acceptance (Arulogun et al., 2020; Kamarulzaman \& Siew, 2020), the present study is deemed significant to discover the true nature of students' engagement on mobile mediamorphosis. Observations by the researchers suggest that the average students' amazement towards mediamorphosis may be misleading. Attention to teaching may not translate to the understanding of the subject matter.

\section{Acknowledgment}

The researchers would like to acknowledge RACER/1/2019/SS109/UITM//1 grant, Universiti Teknologi Mara and the Ministry of Higher Learning Malaysia that have enabled the research to be conducted.

\section{Reference}

Abdeen, T. A. (2016). The attitude of learners towards the use of technology in enhancing English language learning. [Masters dissertation, Sudan University of Science \& Technology]. SUSTECH Repository. http://repository.sustech.edu/handle/123456789/15466

Abdul Majeed, M. R. \& Muslim, I. M. (2016). Technology usage in English language teaching and learning: Reality and dream. Journal of College of Education for Women. 27(6), 
2180-2191.

https://jcoeduw.uobaghdad.edu.iq/index.php/journal/article/view/649/597

Abdul Muin, N. (2021) Supporting and engaging isolated language learners in Open and Distance Learning (ODL) classes a comparative study between a Malaysian and an Indonesian university undergraduate students. Proceedings from International Conference on Language, Education, Humanities \& Social Sciences (i-LEdHS2021), 22 Februari 2021, UiTM Cawangan Kelantan. https://ir.uitm.edu.my/id/eprint/45121/1/45121.pdf

Alfaleh, A. R. (2015). Using technology for developing ESL students' reading comprehension and motivation. International Academic Conference Proceedings, West East Institute . 1-11. https://www.westeastinstitute.com/wp-content/uploads/2015/05/Alia-RajaAlfaleh.pdf

Arulogun, O. T., Akande, O. N., Akindele, A. T., \& Badmus, T. A. (2020). Survey dataset on open and distance learning students' intention to use social media and emerging technologies for online facilitation. Data in Brief. 31. 1-8. https://doi.org/10.1016/j.dib.2020.105929

Bowern, C. (2008). Linguistic fieldwork: A practical guide. Palgrave Macmillian.

Dwyer, A. M. (2006). Ethics and practicalities of cooperative fieldwork. In J. Gippert, N.P. Himmelmann, \& U. Mosel, (Eds). Essentials of language documentation. (pp. 31-66). Mouton De Gruyter.

Dzakiria, H., Idrus, M. R., \& Atan, H. (2005) Interaction in open distance learning: Research issues in Malaysia. Malaysian Journal of Distance Education, 7 (2). 63-77. http://mjde.usm.my/vol7_2_2005/mjde7_2_5.pdf

Fidler, R. F. (1997). Mediamorphosis: Understanding new media. Sage Books Gunuç, S. \& Babacan, N. (2017). Technology integration in English language teaching and learning. The Journal of Teaching English for Specific and Academic Purposes. 5(2). 349-358. http://espeap.junis.ni.ac.rs/index.php/espeap/article/view/524

Huang, R., Tlili, A., Chang, T. W., \& Zhang, X. (2020). Disrupted classes, undisrupted learning during COVID-19 outbreak in China: Application of open educational practices and resources. Smart Learning Environments. 7(19), 1-15. https://doi.org/10.1186/s40561020-00125-8

Ikram, H. (2015). The impact of teachers' professional development in video technology on Mathematics and English learning of preschoolers in a rural primary school in Pakistan. International Journal of Digital Society, 6(3), 1066-1072. DOI:10.20533/ijds.2040.2570.2015.0131

Jiménez, W. C. (2014). The use of ICTs in the BA in English teaching. Revista, 14(1), 1-23. https://www.scielo.sa.cr/scielo.php?script=sci_arttext\&pid=S140947032014000100006

Khodeir, L. M. (2018) Blended learning methods as an approach to teaching project management to architecture students. Alexandria Engineering Journal. 57(4). 38993905. https://doi.org/10.1016/j.aej.2018.10.004

Kimura, M. (2018). ICT, a motivating tool: A case study with Padlet. In the $8^{\text {th }}$ CLS International Conference. Singapore. https://fass.nus.edu.sg/cls/wpcontent/uploads/sites/32/2020/10/kimura_masami.pdf

Kuo, Y. C., Walker, A. E., Belland, B. R., \& Schroder, K. E. E. (2013). A predictive study of student satisfaction in online education programs. The International Review of Research in Open and Distributed Learning. 14(1). 16-39. https://doi.org/10.19173/irrodl.v14i1.1338 
Labov, W. (1972). Some principles of linguistics methodology. Language in Society. 1(1). 97120. 1(1). 97-120. doi:10.1017/S0047404500006576

$\mathrm{Li}, \mathrm{X}$. (2015). Review on "blended learning" in language teaching. English Language and Literature Studies, 5(4). 130-134. http://dx.doi.org/10.5539/ells.v5n4p130

Nomass, B. B. (2013). The impact of using technology in teaching English as a second language. English Language and Literature Studies, 3(1). 111-116. http://dx.doi.org/10.5539/ells.v3n1p111

Paechter, M., Maier, B., \& Macher, D. (2010). Students' expectations of and experiences in eLearning: Their relation to learning achievements and course satisfaction. Computers \& Education. 54(1). 222-229. https://doi.org/10.1016/j.compedu.2009.08.005

Palacios, R. C. (2016). The effect of blended learning (b-learning) on developing vocabulary and reading, a study in the first level of credits course in the Faculty of Medicine of the University of Cuenca, during the school year 2014-2015. (Masters dissertation, National University of De Chimborazo). UNACH Digital Repository. http://dspace.unach.edu.ec/handle/51000/2785

Parsa, M. J. (2015). The effect of web-based and face-to-face discussions in the speaking skill of Iranian students. International Journal of Biology, Pharmacy \& Allied Sciences, 4(5). 2835-2854. https://ijbpas.com/pdf/2015/May/1431064785MS IJBPAS 2015 2654.pdf

Piccoli, G., Ahmad, R., \& Ives, B. (2008). Web-based virtual learning environments: A research framework and a preliminary assessment of effectiveness in basic IT skill training. MIS Quarterly, 25(4), 401-426. https://doi.org/10.2307/3250989

Puteh, M. (2007). eLearning in Malaysian public universities: Case studies of Universiti Kebangsaan Malaysia and Universiti Teknologi Malaysia. In Z. Tasir (Ed.) 1st International Malaysian Educational Technology Convention 2007 Proceedings, 2, (pp. 825-834). META.

http://www.fp.utm.my/ePusatSumber/listseminar/20.KonventionTP2007-

20/pdf/volume2 /108-marlia.pdfRuiz, J.G., Mintzer, M.J. \& Leipzig, R.M. (2006). The impact of elearning in medical education. Academic Medicine, 81(3), 207-212. https://doi.org/10.1097/00001888-200603000-00002

Self, J. (2021). Teaching K-12 science and engineering in during a crisis. The National Academy Press. https://doi.org/10.17226/25909

Solano, L., Cabrera, P., Ulehlova, E., \& Espinoza, V. (2017). Exploring the use of educational technology in EFL teaching: A case study of primary education in the south region of Ecuador. Teaching English with Technology. 17(2), 77-86.

http://cejsh.icm.edu.pl/cejsh/element/ bwmeta1.element.desklight-baa02821-334b4a72-8517-665becf52511

Wibisono, D. (2019). The effects of Kahoot in teaching reading to tenth grade students of senior high school. Magister Scientiae. 45. 86-105. https://doi.org/10.33508/mgs.v1i45.2045

Wu, J. H., Tennyson, R. D., \& Hsia, T. L. (2010), A study of students' satisfaction in a blended eLearning system environment. Computers \& Education. 55(1). 155-164. https://doi.org/10.1016/j.compedu.2009.12.012.

Yusuf, Q., Yusuf, Y. Q., Erdiana, N., \& Pratama, A. R. (2018) Engaging with Edmodo to teach English writing of narrative texts to EFL students. Problems of Education in the $21^{\text {st }}$ Century. 76(3). 333-349. https://doi.org/10.33225/pec\%2F18.76.333 